\title{
CAMBRIDGE LINGUISTICS
}

\section{Talk at Work \\ Interaction in Institutional Settings \\ Paul Drew and \\ John Heritage, Editors \\ A major collection of studies in the application of conversation analysis to the study of professional and client interaction, covers a wide range of institutional settings, including doctor- patient consultations, legal hearings, mass media, job interviews, etc. \\ Contributors: J. Maxwell Atkinson, Jorg Bergmann, Grabam Button, Steven Clayman, Paul Drew, David Greatbatch, John Gumperz, Christian Heath, John Heritage, GailJefferson, Jobn Lee, Stepben Levinson, Douglas Maynard, Emanuel Scbegloff, Sue Sefi, Don Zimmerman Studies in Interactional Soctolingutstics 8 \\ 37489-8 Hardcover $\$ 79.95$ \\ 37633-5 Paper $\$ 29.95$}

\section{Tools, Language} and Cognition in Human Evolution Kathleen R. Gibson and Tim Ingold, Editors

The question addressed by this volume is how human beings have evolved as creatures who can make and use more complex tools, communicate in more complex ways, and engage in more complex forms of social life, than any other species in the animal kingdom. 41474-1 Hardcover $\$ 69.95$

\section{Nonverbal Vocal Communication}

Comparative and

Developmental Approaches H. Papoušek, U. Jürgens,

M. Papoušek, Editors

Specialists from several disciplines review the present knowledge on neural substrates of vocal communication, on primate vocal communication, and on precursors and prerequisites of human speech.

Studies in Emotion and Soctal Interaction

41265-X Hardcover $\$ 54.95$

\section{English in Language Shift}

The History, Structure and Sociolinguistics of South African Indian English

\section{Rajend Mesthrie}

This study examines the rise of a new variety of English among Indian migrant workers indentured on the plantatios of Natal in South Africa. Considering the historical background to, and linguistic consequences of, language shift in an immigrant context, it draws significant parallels between second language acquisition and the processes of pidginisation and creolisation. 41514-4 Hardcover $\$ 64.95$

Now in paperback...

\section{Discourse Structure and Anaphora}

Written and Conversational English

\section{Barbara A. Fox}

This study examines the distribution of pronouns and full noun phrases in three different genres of English, and demonstrates the relationships between the hierarchical structure of discourses and the use of anaphoric phrases within those discourses.

43990-6 Paper $\$ 17.95$

\section{English Phonology}

An Introduction

\section{Heinz J. Giegerich}

This introduction to the phonology of present-day English offers a systematic and detailed discussion of the features shared by three varieties of English:

"General American," Southern British

"Received Pronunciation" and "Scottish Standard English."

33303-2 Hardcover $\$ 69.95$

33603-1 Paper $\$ 19.95$

Available in bookstores or from

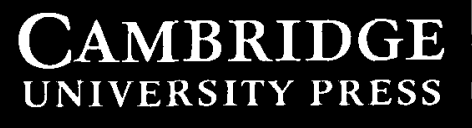

40 West 20th St., N.Y., NY 10011-4211

Call toll-free 800-872-7423

MasterCard/VISA accepted. Prices subject to change. 


\section{2nd Annual Conference on New Ways of Analyzing Variation}

\section{October 14 - 17, 1993 \\ oniversity of ottawa}

The keynote speakers are Jack Chambers, William Labov, and walt Wolfam.

Workshops on the following topics will be offered:

1. Henrietta Cedergren

The Phonetic Analysis of Rhythmic Structure in Spontaneous Speech

2. William Labov

Spatial Variation: Current Computational Techniques and Principles for Geographic Reasoning

3. David Sankoff and Sali Tagliamonte

Interpreting Variable Rule Results: Answers to Questions

You Always Wanted To Ask

For more information, contact:

Shana Poplack / NWAVE 22

Department of Linguistics

University of Ottawa

78 Laurier East

ottawa K1N 6N5 CANADA

E-mail: NWAVE22 @ACADVM1.UOTTAWA.CA

Fax: 613-564-9067 


\section{\& Language Varlation and Change}

\section{NOTES FOR CONTRIBUTORS}

Language Variation and Change publishes original research reports that are based on data of language production, either oral or written, from contemporary or historical sources. Articles with substantive content are preferred over those that are solely argumentative; those that synthesize or reanalyze a number of research findings on substantive issues will also be considered. Conforming to scientific methodology, the reported findings should be fully replicable from the information provided.

Contributions may be submitted from all countries. The usual language of publication is English, although articles in French are also welcome. All submissions should be sent, in triplicate, to:

David Sankoff

\section{Language Variation and Change}

Centre de recherches mathematiques

Université de Montréal

C.P. 6128, Succursale "A"

Montréal H3C 3J7, Canada

Submission of an article is taken to imply that it has not been previously published or is not being considered for publication elsewhere. If an author is publishing a related article, this fact should be stated.

Copyright. Contributors of accepted articles will be asked to assign their copyrights, on certain conditions, to Cambridge University Press, to help protect their material, particularly in the U.S.A.

\section{Manuscript Preparation and Style}

Manuscripts should be clearly typed on $81 / 2 " \times 11^{\text {" }}$ or A4 white bond paper. The inclusion of microcomputer diskettes containing text, artwork, and appropriate software, along with the hard copy, may facilitate editing. The entire manuscript-including abstract, endnotes, references, and tables - must be double-spaced and numbered consecutively. The Editor may find it necessary to return manuscripts for reworking or retyping that do not conform to the journal's requirements. The article should be arranged as follows:

Title Page (page 1). To facilitate blind reviews, all indication of authorship must be limited to this page. Other pages must only show the short title plus page number in the upper right corner. The title page includes (a) full title, (b) names and affiliations of all authors, (c) mailing address and phone number of the lead author, (d) address to which offprints should be sent (if not the lead author), (e) short title of less than 50 characters.

Abstract (page 2). Include the full title and the abstract. Abstracts should not exceed 150 words.

Acknowledgments (page 2). Place below the abstract. Use this section to indicate any grant support, substantial assistance in the preparation of the article, or any other author notes.

Text (page 3). Use a S-character paragraph indent. Do not hyphenate words or justify the right margin. Underscore material that is to be italicized in print. Glosses should be placed within single quotation marks.

References are to be made in the text (not in the endnotes) by giving in parentheses the name of the author, year of publication, and, where relevant, the page(s) referred to:
(Vincent, 1982:90-91). If the author's name is part of the text, the following form should be used: "Vincent (1982) listed several. . . " For multi-authored works, only the first citation should list all authors: (Weinreich, Labov, \& Herzog, 1968). In subsequent citations, only the first name should be given, followed by "et al.": (Weinreich et al., 1968). Separate works referred to in the same parentheses should be listed in alphabetical order; those by the same author should be separated by commas, and those by different authors by semi-colons: (López Morales, 1981; Vincent, 1981, 1982). Initials should be used (before the author's name) only when it is necessary to distinguish between two or more authors with the same surname referred to in the same article.

All works referred to in the text must be listed in the ref. erence section, double-spaced and in alphabetical order.

Examples of references (note the use of punctuation marks within references):

Cedergren, Henrietta J. (1973). Interplay of social and linguistic factors in Panama. Ph.D. dissertation, Cornell University.

López Morales, Humberto. (1981). Velarization of $/ n /$ in Puerto Rican Spanish. In D. Sankoff \& H. J. Cedergren (eds.), Variation omnibus. Edmonton: Linguistic Research, Inc. 105-113.

Tagliamonte, Sali, \& Poplack, Shana. (1980). How Black English Past got to the present: Evidence from Samaná. Language in Society 17:513-533.

Vincent, Diane. (1982). Pressions et impressions sur les sacres au Québec. Montréal: Office de la langue française.

Endnotes may be used when more than a simple citation is required. Notes should be numbered consecutively throughout the text and typed together on a separate page preceding the reference section.

Tables. Tables must appear as a unit following the reference section. Each table should be typed, doublespaced, on a separate sheet, numbered consecutively with an Arabic numeral and a short title. All tables must be cited in the text.

Figures. Figures must appear as a unit following the tables. Figures must be ready for photographic reproduction: for photographs, an 8" $\times 11$ " glossy; or for diagrams, professionally rendered or computer generated. All labels and details must be clearly printed and large enough to remain legible at a $50 \%$ reduction. Each figure must be numbered consecutively with an Arabic number. Descriptive legends must be typed together, double-spaced, on a separate sheet preceding the artwork. Artwork should be identified by number and title on the back and be carefully packaged in a protective envelope. All figures must be cited in the text.

\section{Proofs}

First proofs will be sent to the lead author who will be expected to correct and return them to the Editor, by airmail where appropriate, within 3 days of receipt.

\section{Offprints}

25 offprints of the article will be provided free of charge to the lead author. Additional offprints may be purchased if ordered at the proof stage. 


\section{Language Variation and Change}

Volume 4 Number 31992

\section{CONTENTS}

Janet Holmes and Allan Bell

On shear markets and sharing sheep: The merger of EAR and AIR diphthongs in New Zealand English

Otto Santa Ana A.

Chicano English evidence for the exponential hypothesis:

A variable rule pervades lexical phonology

JOHN MYHILL

Verb position in future clauses in Biblical Hebrew

DONALD WINFORD

Back to the past: The BEV/creole connection revisited

Contents for Volume 4 (1992) 